\title{
PENINGKATAN MUTU DAN DAYA SIMPAN IKAN PINDANG KUNING "PINDANG RUMBUK" DENGAN PERLAKUAN LAMA STERILISASI
}

\author{
[The Enhancement of Quality and Shelf Life of Yellow Seasoned Pindang Fish "Pindang Rumbuk" \\ Through Treatment of Sterilization Time]
}

\author{
Mirriyadhil Jannah'1), Baiq Rien Handayani1)*, Bambang Dipokusumo'), Wiharyani Werdiningsih ${ }^{1)}$ \\ 1) Fakultas Teknologi Pangan dan Agroindustri, Universitas Mataram \\ 2) Fakultas Pertanian-Universitas Mataram \\ *Email: baiqrienhs@yahoo.com
}

\begin{abstract}
Processing of yellow seasoned pindang fish known as pindang rumbuk only able to maintain the quality and shelf life for 24 hours at room temperature. The purpose of this study was to determine the quality and the shelf life of yellow pindang fish treated with sterilization time. The design used in this study was Completely Randomized Design (CRD) with a single factor of sterilization time with 6 treatments ie.sterilization for 0, 5, 10, 15, 20 and 25 minutes. Parameters observed at days 0, 14, 28 and 42 days at room temperature consisted of: $\mathrm{pH}$, microbial quality (total microbe and total fungi), organoleptic quality in hedonic supported by score test (appearance, aroma, taste and texture) and shelf life observation visually. Data of $\mathrm{pH}$ and organoleptic values were analyzed using Anova using Co-Stat software and different treatment were tested further by using real difference with $5 \%$ real level. While microbial data and shelf life were analyzed by using descriptive method. The results showed that the duration of sterilization had significantly different effect on the $\mathrm{pH}$ value of the yellow seasoned pindang fish during storage 0, 14 and 42 days, but had no effect on 28 day storage. The treatment of 15 to 25 minutes sterilization was able to produce produce total microbe and total mold in accordance to SNI 2717.1: 2009. It was also able to maintain the organoleptic quality of the parameters of appearance, aroma, taste and texture during 42 days storage at room temperature and maintain the quality of yellow seasoned pindang fish from the growth of mushrooms visually, prevent bottle fromswelling, gas bubble formation and color changes. The duration of sterilization of 15 minutes is recommended as the minimum sterilization time used to improve the quality and shelf life of yellow seasoned pindang fish up to 42 days at room temperature.
\end{abstract}

Keywords: fish seasoning pindang yellow, quality, shelf life, sterilization.

\section{ABSTRAK}

Pengolahan ikan pindang bumbu kuning yang dikenal dengan pindang rumbuk hanya mampu mempertahankan mutu dan daya simpan selama 24 jam pada suhu ruang. Tujuan dari penelitian ini adalah untuk mengetahui mutu dan daya simpan Ikan Pindang Kuning yang diberi perlakuan lama sterilisasi. Rancangan yang digunakan pada penelitian ini adalah Rancangan Acak Lengkap (RAL) dengan faktor tunggal lama sterilisasi dengan 6 perlakuan yaitu sterilisasi 0 menit, 5 menit, 10 menit, 15 menit, 20 menit dan 25 menit. Parameter yang diamati pada hari ke 0, 14, 28 dan 42 hari pada suhu ruang terdiri dari: $\mathrm{pH}$, mutu mikrobiologi (total mikroba dan total kapang), mutu organoleptik secara hedonik dan skoring (kenampakan, aroma, rasa dan tekstur) serta pengamatan daya simpan secara visual. Data hasil pengamatan nilai pH dan organoleptik dianalisis menggunakan Anova menggunakan software Co-Stat dan perlakuan yang berbeda nyata diuji lanjut dengan menggunakan Beda nyata Jujur (BNJ) dengan taraf nyata $5 \%$. Sedangkan data hasil pengamatan mikrobiologis dan daya simpan dianalisis dengan menggunakan metode deskriptif. Hasil penelitian menunjukkan bahwa lama sterilisasi memberikan pengaruh yang berbeda nyata terhadap nilai pH ikan pindang bumbu kuning selama penyimpanan 0,14 dan 42 hari, namun tidak berpengaruh pada penyimpanan 28 hari. Perlakuan sterilisasi 15 sampai dengan 25 menit dapat menghasilkan total mikroba dan total kapang yang sesuai dengan standar SNI 2717.1:2009, mampu mempertahankan mutu organoleptik dari parameter kenampakan, aroma, rasa dan tekstur selama penyimpanan 42 hari pada suhu ruang dan mempertahankan mutu daya simpan ikan pindang bumbu kuning dari pertumbuhan kapang secara visual, mencegah penggembungan tutup botol, pembentukan gelembung gas dan perubahan warna ikan pindang bumbu kuning. Lama sterilisasi 15 menit direkomendasikan sebagai lama sterilisasi minimal yang digunakan untuk meningkatkan mutu ikan pindang bumbu kuning dilihat dari nilai $\mathrm{pH}$, total mikroba, total kapang, mutu organoleptik dan daya simpan ikan pindang bumbu kuning.

Kata Kunci: daya simpan, ikan pindang bumbu kuning, mutu, sterilisasi

\section{PENDAHULUAN}

Indonesia merupakan Negara yang mempunyai potensi perikanan yang cukup tinggi karena sebagian daerahnya terdiri dari lautan. Potensi perikanan Indonesia pada tahun
2011 mencapai sekitar 65 juta ton pertahun (Dahuri, 2012). Berdasarkan Badan Pusat Statistik tahun 2013, jumlah produksi perikanan di Nusa Tenggara barat (NTB) sebesar $142.187,4$ ton. Potensi perikanan tangkap di Lombok Timur mencapai $12.691,5$ ton. 
Berdasarkan data tahun 2009 (BPS, 2013) dengan hasil tangkapan di Desa Tanjung Luar Lombok Timur mencapai lebih 1000 ton, diantaranya yaitu ikan Tongkol 2000 ton, ikan Tuna 1.163 ton dan ikan Cakalang 1.666,5 ton. Ikan Cakalang merupakan salah satu jenis ikan yang mengandung komponen gizi yang cukup tinggi, khususnya protein, lemak, asam amino esensial dan non esensial serta kandungan mineral seperti $\mathrm{K}, \mathrm{Na}, \mathrm{Ca}, \mathrm{Fe}, \mathrm{Cu}$ dan $\mathrm{Zn}$ (Attygale, 2009 dalam Ekawati, 2014). Selain sebagai sumber bahan pangan yang bergizi tinggi, ikan Cakalang juga termasuk bahan pangan yang sangat mudah mengalami proses pembusukan (Hawora, 2013). Salah satu cara untuk mempertahankan mutu ikan Cakalang yaitu dengan melakukan proses pengolahan pada ikan. Metode pengolahan pada ikan Cakalang yang sering dilakukan oleh masyarakat Tanjung Luar adalah pemindangan.

Pemindangan adalah salah satu cara pengolahan ikan segar dengan kombinasi perlakuan antara penggaraman dan perebusan (Adawyah, 2007). Pemanasan dan penggaraman ini berfungsi untuk menginaktifkan enzim, membunuh mikroba patogen, mengubah sifat fisik, sehingga mudah dicerna serta memperbaiki cita rasa dan tekstur (Suryaningrum, Syamdidi dan Rizki, 2013). Ada beberapa jenis ikan pindang di Indonesia antara lain yaitu pindang cue, pindang naya, pindang tongkol, pindang bandeng, pindang pekalongan, pindang layang, pindang cakalang, pindang garam, pindang presto dan pindang bumbu. Jenis pindang bumbu yang dikenal oleh masyarakat Lombok adalah ikan pindang bumbu kuning yang dikenal dalam bahasa lokal sebagai pindang Rumbuk. Ikan pindang bumbu kuning merupakan bentuk diversifikasi pengolahan ikan pindang dengan menggunakan bumbu dasar yang terdiri dari garam, kunyit dan asam. Pengolahan pindang ini sering dilakukan oleh masyarakat Desa Rumbuk, Lombok Timur. Menurut Sugita (2017), ikan pindang bumbu kuning dibuat dengan menggunakan kunyit $6 \%$ dan asam jawa $4 \%$ yang menghasilkan pindang dengan nilai $\mathrm{pH}$ dan kadar air memenuhi SNI, diterima secara organoleptik dan mengandung jumlah total mikroba $<1,0 \times 10^{3} \mathrm{CFU} / \mathrm{g}$ serta jumlah total kapang sebesar $<1,0 \times 10^{2} \mathrm{CFU} / \mathrm{g}$. Selain itu Handayani, dkk., (2017) menyatakan bahwa dengan menggunakan konsentrasi kunyit dan asam tersebut menghasilkan jumlah total E.coli $<3 \mathrm{APM} / \mathrm{g}$, total Salmonella negatif/25 g, total bakteri Staphylococcus aureus $<3 \mathrm{CFU} / \mathrm{g}$ dan total bakteri Vibrio cholerae negatif/25 g.
Walaupun mengandung beberapa total patogen dan total mikroba yang rendah, karena tidak diberikan perlakuan hurdle yang lain, sehingga ikan pindang bumbu kuning yang dihasilkan tidak dapat disimpan lama. Ikan pindang yang dihasilkan hanya mampu bertahan 24 jam pada suhu kamar sehingga akan menyulitkan produsen/UKM setempat dalam pengembangannya. Oleh karena itu perlu dicarikan alternatif pengolahan lebih lanjut untuk mempertahankan daya simpan ikan pindang bumbu kuning yaitu dengan cara pengalengan.

Pengalengan pangan merupakan suatu prosedur pengawetan pangan menggunakan kemasan yang tertutup secara hermetis dan memanaskannya untuk membunuh mikroorganisme patogen, penyebab kebusukan maupun sporanya, serta untuk menginaktivasi enzim yang dapat merusak mutu (Sharma, dkk., 2000 dalam Sholihah, 2011). Teknologi ini dapat mempertahankan daya simpan produk sampai lebih dari enam bulan (Hariyadi, Kusnandar dan Wulandari, 2006). Pengalengan biasanya dilakukan pada suhu sterilisasi yaitu $121^{\circ} \mathrm{C}$ selama 20 menit. Menurut Muhtadi (1994) dalam Utami (2012), sterilisasi bertujuan untuk menghancurkan mikroba pembusuk dan patogen serta membuat tekstur dan citarasa produk menjadi lebih baik. Nurhikmat, dkk., (2016) menyebutkan bahwa sterilisasi harus dilakukan pada kisaran suhu $121{ }^{\circ} \mathrm{C}$ pada waktu tertentu, dimana panas yang diberikan cukup untuk menghancurkan bakteri patogen dan tidak menurunkan kualitas gizi dan organoleptik makanan yang dikalengkan. Nurida dan Bashirun (2013) memperlihatkan bahwa ikan rendang patin dalam kaleng yang disterilisasi pada suhu 121 ${ }^{\circ} \mathrm{C}$ selama 20 menit dengan tekanan $2 \mathrm{~atm}$ menghasilkan ALT anaerob $<10 \mathrm{kol} / \mathrm{g}$, kadar air $60,12 \%$, kadar abu 1,84\%, kadar lemak $25,64 \%$ dan kadar protein $12,40 \%$. Selain itu Saputra (2006) menyatakan bahwa tempe yang dikemas secara vakum dan disterilisasi pada suhu $121^{\circ} \mathrm{C}$ selama 15 menit mampu mempertahankan masa simpan tempe selama 8 minggu dengan kandungan total mikroba sebesar $10 \mathrm{CFU} / \mathrm{g}$. Penelitian lain yang dilakukan Fernandez (2017) pada gulai remis dengan perlakuan lama sterilisasi memperlihatkan bahwa jumlah total mikroba gulai remis semakin menurun dengan semakin lamanya sterilisasi dan perlakuan sterilisasi selama 20 menit direkomendasikan sebagai perlakuan terbaik sesuai dengan SNI 7388:2009. Optimasi proses termal diperlukan 
untuk dapat menentukan kombinasi suhu dan waktu selama pemanasan dan pendinginan yang dapat memenuhi kriteria kemanan pangan dan mutu, sejalan dengan pernyataan Yuswita (2014). Penerapan teknik pengalengan/pembotolan dengan perlakuan lama sterilisasi pindang kuning belum pernah dilakukan. Oleh karena itu, penelitian ini bertujuan meningkatkan mutu ikan pindang kuning dengan menerapkan lama sterilisasi ikan pindang bumbu kuning yang dikalengkan.

\section{Bahan}

\section{METODOLOGI}

Bahan-bahan yang digunakan dalam penelitian antara lain: ikan Cakalang segar yang diperoleh dari pasar Kebon Roek. Bumbu yang digunakan adalah kunyit, asam jawa, garam beryodium. Bahan kimia yang digunakan adalah Medium Potato Dextrose Agar/PDA (merk Oxoid CM0139), Plate Count AgarPCA (merk Oxoid CM0325), larutan buffer phosphate, aquades dan alkohol.

\section{Metode \\ Pembuatan Bumbu}

Proses pembuatan bumbu dilakukan dengan tahapan sebagai berikut: bumbubumbu yang digunakan dalam pembuatan pindang ikan bumbu kuning terdiri dari kunyit segar halus sebanyak $900 \mathrm{~g}(6 \%)$, asam jawa sudah dihaluskan sebanyak $600 \mathrm{~g}(4 \%)$ dan garam sebanyak 289,5 g (1,93\%) (Sugita, 2017). Selanjutnya seluruh bumbu digiling dan ditambahkan air sebanyak $3200 \mathrm{~mL}(64 \%)$.

\section{Proses Pengolahan Ikan Pindang Kuning}

Proses pengolahan ikan pindang bumbu kuning mengikuti Sugita (2017) dengan cara sebagai berikut yaitu daging ikan cakalang yang sudah diiris dengan ukuran lebar $\pm 1-2 \mathrm{~cm}$, panjang $\pm 2-3 \mathrm{~cm}$ dan tinggi $\pm 3-5 \mathrm{~cm}$ (berat 1 irisan ikan \pm 6-7 gram). Ikan yang sudah diiris dicuci bersih dan dicampur dengan adonan bumbu dan dilakukan pemasakan pada suhu $100^{\circ} \mathrm{C}$ selama \pm 5 menit.

\section{Pembotolan}

Proses pengalengan ikan pindang bumbu kuning dalam botol kaca mengikuti prosedur Fernandez (2017) sebagai berikut: ikan pindang bumbu kuning masak dimasukkan ke dalam botol kaca steril steril dengan berat ikan \pm 100 gram dan kuah pindang $90 \mathrm{ml}$. Jarak headspace antara bahan dengan penutup botol kaca adalah $\pm 2 \mathrm{~cm}$. Kemudian, dilakukan proses exhausting menggunakan waterbath pada suhu $80^{\circ} \mathrm{C}$ selama 10 menit. Setelah itu dilakukan penutupan botol. Proses selanjutnya yaitu sterilisasi suhu $121^{\circ} \mathrm{C}$ selama $0,5,10,15$, 20 dan 25 menit serta pendinginan sampai suhu mencapai $38-40^{\circ} \mathrm{C}$. Setelah produk ikan pindang bumbu kuning dingin kemudian disimpan pada suhu ruang $\left(30^{\circ} \mathrm{C}\right)$ dan dilakukan pengamatan pada hari ke-0, 14, 28, dan 42 hari.

\section{Rancangan percobaan}

Rancangan yang digunakan pada penelitian ini adalah Rancangan Acak Lengkap (RAL) dengan faktor tunggal lama sterilisasi dengan 6 perlakuan yaitu sterilisasi 0 menit, 5 menit, 10 menit, 15 menit, 20 menit dan 25 menit. Parameter yang diamati pada hari ke 0 , 14, 28 dan 42 hari pada suhu ruang terdiri dari: pH (SNI-06-6989-11-2004), mutu mikrobiologi (total mikroba menggunakan metode tuang dan total kapang menggunakan metode sebar) (modifikasi SNI 1-2332-3-2006), mutu organoleptik secara hedonik dan skoring (kenampakan, aroma, rasa dan tekstur) (modifikasi SNI 2346-2011) serta pengamatan daya simpan secara visual. Data organoleptik meliputi kenampakan, aroma, rasa dan tekstur dinyatakan dalam skala numerik (hedonik: $1=$ sangat tidak suka, $2=$ tidak suka, $3=$ agak suka, $4=$ suka dan 5 = sangat suka), sedangkan mutu organoleptik secara skoring dengan kriteria kenampakan ( $1=$ Hancur, daging merah, sangat kusam, 2= Agak hancur, tercampur daging merah, kusam, $3=$ Serpihan semua, tercampur daging merah, pudar, 4= Banyak serpihan, kurang bersih, terdiri dari daging putih kekuningan dan daging merah, kurang cemerlang, 5= Banyak serpihan, bersih terdiri dari daging putih kekuningan, sedikit kurang cemerlang, $6=$ Utuh, ada sedikit serpihan, rapi, bersih terdiri daging putih kekuningan, cemerlang, 7= Rapi, bersih terdiri daging putih kekuningan, cemerlang), aroma (1= Busuk dan asam meningkat, $2=$ Sudah busuk dan asam, $3=$ Tidak segar, netral, 4= Kurang segar, netral, $5=$ Kurang segar, kurang harum, khas ikan kaleng hampir hilang, 6= Kurang segar, harum ikan kaleng, $7=$ Segar, harum, khas ikan kaleng), rasa ( $1=$ Basi meningkat, $2=$ Tidak enak, terasa basi, $3=$ Tidak enak, hambar, 4= Kurang enak, mendekati netral, $5=$ Kurang enak, kurang putih, $6=$ Enak, sedikit kurang gurih, 7= Enak, gurih, rasa ikan segar), tekstur (1= Lembek sekali, 2= Lembek, tidak kompak, $3=$ Kurang padat, kurang kompak, 4= Padat, kurang kompak, 5= Padat, sedikit kompak, $6=$ Padat, kompak, 7= Padat, sangat kompak. 


\section{Analisa data}

Data hasil pengamatan nilai $\mathrm{pH}$ dan organoleptik dianalisis menggunakan Anova menggunakan software Co-Stat dan perlakuan yang berbeda nyata diuji lanjut dengan menggunakan Beda nyata Jujur (BNJ) dengan taraf nyata $5 \%$. Sedangkan data hasil pengamatan mikrobiologis dan daya simpan dianalisis dengan menggunakan metode deskriptif (Wahyuni, 2017).

\section{HASIL DAN PEMBAHASAN}

\section{Mutu Kimia}

Nilai pH

Salah satu mutu kimia ikan pindang bumbu kuning yang dianalisa yaitu nilai $\mathrm{pH}$. Nilai pH selama penyimpan ikan pindang selama 42 hari tertera pada Gambar 1.

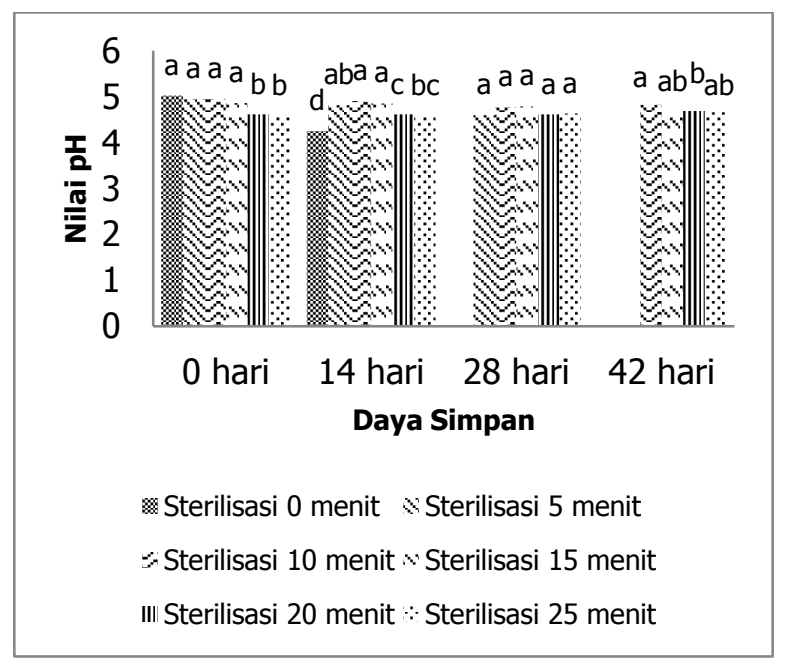

Gambar 1. Grafik Pengaruh Lama Sterilisasi terhadap pH Ikan Pindang Bumbu Kuning selama Penyimpanan 42 Hari

Berdasarkan Gambar 1, perlakuan lama sterilisasi memberikan hasil yang berbeda nyata terhadap nilai $\mathrm{pH}$ ikan pindang bumbu kuning selama penyimpanan 0,14 dan 42 hari, namun tidak berbeda nyata nyata terhadap nilai $\mathrm{pH}$ ikan pindang bumbu kuning pada penyimpanan 28 hari. Nilai pH awal perlakuan tanpa sterilisasi ikan pindang kuning kaleng pada penyimpanan 0 hari adalah 5,02. Nilai $\mathrm{pH}$ yang rendah ini disebabkan karena penambahan bumbu seperti kunyit dan asam jawa. Nilai pH kunyit adalah 6,42, sedangkan nilai $\mathrm{pH}$ asam jawa adalah 3,20 . Kombinasi bumbu kunyit $6 \%$ dan asam jawa sebanyak $4 \%$ menghasilkan nilai $\mathrm{pH}$ sebanyak 4,82. Sehingga menurut Sugita (2017), kandungan nilai pH ikan pindang bumbu kuning dengan kombinasi kunyit 6\% dan asam jawa $4 \%$ menghasilkan nilai $\mathrm{pH}$ sebesar 5,01.

Perbedaan nilai $\mathrm{pH}$ ikan pindang bumbu kuning disebabkan karena lama waktu sterilisasi yang berbeda-beda. Penggunaan suhu sterilisasi yang tinggi juga menyebabkan pH ikan pindang bumbu kuning menurun. Hal yang sama juga dikemukakan Wahyuni (2017) yang menyatakan bahwa semakin lama waktu sterilisasi, maka nilai pH ares semakin menurun. Sedangkan Fernandez (2017) memperlihatkan bahwa semakin lama waktu sterilisasi menyebabkan penurunan $\mathrm{pH}$ gulai remis. Kecenderungan semakin menurunnya $\mathrm{pH}$ seiring dengan naiknya suhu pemanasan. Hal ini diduga disebabkan oleh naiknya energi panas yang terdapat pada pelarut (air), semakin banyak melarutkan komponen kimia pada rimpang kunyit dan asam jawa yang bersifat asam serta menyebabkan adanya penambahan $\mathrm{H}^{+}$dalam larutan sehingga konsentrasi $\mathrm{H}^{+}$yang tinggi akan menyebabkan larutan menjadi asam atau $\mathrm{pH}$ menurun.

Ikan pindang yang disimpan selama 14 hari mengalami penurunan nilai $\mathrm{pH}$. Penurunan $\mathrm{pH}$ tertinggi ikan pindang bumbu kuning terdapat pada perlakuan tanpa sterilisasi yaitu 4,25. Penurunan $\mathrm{pH}$ ini disebabkan karena adanya pertumbuhan mikroba. Sugitha dan Djalil (1989) dalam Wahyuni (2017) mengatakan bahwa penurunan $\mathrm{pH}$ disebabkan oleh aktivitas mikroorganisme di dalam makanan selama penyimpanan yang dapat menyebabkan terjadinya fermentasi dan menghasilkan asam. Hal yang sama terjadi pada ikan pindang pada penyimpanan 28 hari namun tidak berbeda nyata antar semua perlakuan. Perlakuan sterilisasi 5 menit terjadi penurunan $\mathrm{pH}$ menjadi 4,60. Hal ini diduga disebabkan adanya aktivitas mikroorganisme yang meningkat melebihi batas cemaran menurut SNI 2717.1:2009 yaitu $1 \times 10^{5} \mathrm{CFU} / \mathrm{g}$ di dalam bahan makanan dan menyebabkan terjadinya perombakan nutrisi dan menghasilkan asam-asam organik sehingga nilai pH menurun. Menurut Soeparno (1996) dalam Wahyuni (2017) bahwa salah satu faktor utama yang mempengaruhi $\mathrm{pH}$ adalah mikroorganisme begitu pula sebaliknya. Selama penyimpanan ikan pindang bumbu kuning diikuti dengan penurunan $\mathrm{pH}$ ikan pindang bumbu kuning. Kondisi asam pada ikan pindang bumbu kuning selain disebabkan oleh penggunaan asam jawa juga disebabkan oleh terjadinya penguraian lemak menjadi gliserol dan asam-asam lemak oleh mikoba. Diduga ada 
mikroba tahan asam yang masih dapat tumbuh pada ikan pindang dalam botol yang dihasilkan. Menurut Sholihah (2011), Nilai pH di atas 4,6 memungkinkan bakteri pembusuk anaerobik dan pembentuk spora yang patogen seperti Clostridium botulinum dapat tumbuh. Beberapa spora bakteri dapat tumbuh sampai kira-kira pH 3,7, seperti Bacillus thermoacidurans atau Bacillus coagulans. Sedangkan bahan pangan dengan nilai $\mathrm{pH}$ di bawah 3,7 tidak rusak oleh bakteri berspora. Salah satu bakteri yang mempengaruhi pH makanan kaleng yaitu Bacillus stearothermophillius. Pada penyimpanan 42 hari, nilai $\mathrm{pH}$ ikan pindang bumbu kuning pada perlakuan sterilisasi 15 menit mengalami penurunan diduga karena pada perlakuan sterilisasi 15 menit, terdapat pertumbuhan mikroba yang semakin tinggi yaitu sebesar $4,8 \times 10^{4} \mathrm{CFU} / \mathrm{g}$ sehingga nilai $\mathrm{pH}$ ikan pindang bumbu kuning semakin menurun. Sedangkan pada perlakuan sterilisasi 10 menit, 20 menit dan 25 menit terjadi peningkatan nilai $\mathrm{pH}$ ikan pindang bumbu kuning. Hal ini diduga karena enzim-enzim pengurai seperti enzim proteolitik dapat merombak senyawa protein menghasilkan amoniak yang sifanya basa sehingga $\mathrm{pH}$ meningkat. Menurut Riyanto dkk (2006) dalam Wally (2015), nilai pH berhubungan dengan aktivitas bakteri dan enzim yang secara alami sudah ada. Kondisi ini menyebabkan peningkatan $\mathrm{pH}$ yang mengakibatkan pembentukan amonia, TMA, dan turunannya. Chamidah (2000) dalam Kaparang (2013) menyatakan bahwa selama penyimpanan terjadi penguraian protein menjadi senyawa basa antara lain amoniak. Nilai pH bahan pangan selama penyimpanan dapat berubah karena adanya protein yang terurai oleh enzim proteolitik dan bantuan bakteri menjadi asam karboksilat, asam sulfida, amoniak dan jenis asam lainnya. Menurut Zakaria (1996) dalam Kaparang (2013) bila jumlah asam lebih banyak dari amoniak maka nilai $\mathrm{pH}$ menjadi rendah.

\section{Mutu Mikrobiologis}

Pertumbuhan mikroba pada produk pangan sangat mempengaruhi mutu dan daya simpan produk pangan tersebut. Adanya kontaminasi mikroorganisme dalam bahan pangan dapat menyebabkan kerusakan dan masa simpan menjadi singkat. Adapun dalam penelitian ini dianalisis pengaruh lama sterilisasi terhadap masa simpan ikan pindang bumbu kuning selama penyimpanan dilihat dari total mikroba dan total kapang.

\section{Total Mikroba}

Perlakuan pengaruh lama sterilisasi terhadap total mikroba ikan pindang bumbu kuning selama penyimpanan 42 hari dapat dilihat pada Tabel 1.

Tabel 1. Pengaruh Lama Sterilisasi terhadap Total Mikroba Ikan Pindang Bumbu Kuning selama Penyimpanan 42 Hari

\begin{tabular}{|c|c|c|c|c|}
\hline \multirow{2}{*}{$\begin{array}{c}\text { Lama } \\
\text { Sterilisasi } \\
\text { (menit) }\end{array}$} & \multicolumn{4}{|c|}{$\begin{array}{c}\text { Total mikroba (CFU/g) } \\
\text { Lama Penyimpanan (hari) }\end{array}$} \\
\hline & 0 & 14 & 28 & 42 \\
\hline 0 & $\begin{array}{l}<1,0 \times 10^{1} \mathrm{sd} \\
2,6 \times 10^{5}\end{array}$ & $>1,0 \times 10^{7}$ & TD & TD \\
\hline 5 & $\begin{array}{c}<1,0 \times 10^{1} \mathrm{sd} \\
2,7 \times 10^{3}\end{array}$ & $4,9 \times 10^{5}$ & $>1,0 \times 10^{5}$ & TD \\
\hline 10 & $\begin{array}{l}<1,0 \times 10^{1} \mathrm{sd} \\
2,7 \times 10^{3}\end{array}$ & $1,2 \times 10^{4}$ & $\begin{array}{l}3,2 \times 10^{4} \mathrm{sd} \\
>1,0 \times 10^{5}\end{array}$ & $\begin{array}{c}<1,0 \times 10^{1} \mathrm{sd} \\
1,3 \times 10^{5}\end{array}$ \\
\hline 15 & $\begin{array}{c}<1,0 \times 10^{1} \mathrm{sd} \\
2,6 \times 10^{3}\end{array}$ & $2,7 \times 10^{4}$ & $3,9 \times 10^{4}$ & $\begin{array}{c}<1,0 \times 10^{1} \mathrm{sd} \\
4,8 \times 10^{4}\end{array}$ \\
\hline 20 & $2,6 \times 10^{3}$ & $5,6 \times 10^{3}$ & $1,1 \times 10^{4}$ & $7,4 \times 10^{4}$ \\
\hline 25 & $\begin{array}{c}<1,0 \times 10^{1} \mathrm{sd} \\
5,8 \times 10^{2}\end{array}$ & $\begin{array}{c}<1,0 \times 10^{1} \\
\text { sd } \\
1,5 \times 10^{3}\end{array}$ & $5,5 \times 10^{3}$ & $8,7 \times 10^{3}$ \\
\hline
\end{tabular}

Keterangan: TD = tidak dilakukan

Hasil analisis total mikroba ikan pindang bumbu kuning pada Tabel 1 menunjukkan bahwa pada penyimpanan hari ke-0, jumlah pertumbuhan mikroba ikan pindang bumbu kuning untuk perlakuan tanpa sterilisasi yaitu $<1,0 \times 10^{3}-2,6 \times 10^{5} \mathrm{CFU} / \mathrm{g}$. Perlakuan dengan sterilisasi memiliki jumlah pertumbuhan mikroba tertinggi sebesar $2,7 \times 10^{3} \mathrm{CFU} / \mathrm{g}$ dan terendah $<1,0 \times 10^{1} \mathrm{CFU} / \mathrm{g}$. Perlakuan dengan sterilisasi ini masih memenuhi standar atau berada diatas batas cemaran mikroba pada ikan pindang yang ditetapkan dengan nomor SNI 2717.1:2009 yaitu $1 \times 10^{5} \mathrm{CFU} / \mathrm{g}$. Penurunan jumlah total mikroba ini disebabkan karena penggunaan suhu $121^{\circ} \mathrm{C}$ selama periode waktu tertentu akan menyebabkan penurunan jumlah pertumbuhan mikroba seiring dengan lamanya waktu sterilisasi yang diberikan. Menurut Nurhikmat, dkk. (2015), populasi mikroba ini berasal dari jenis mikroba termofil dan mesofil yang tahan panas yang berkembang biak semakin lamanya penyimpanan, kemungkinan lainnya adalah pada saat preparasi bahan untuk analisis mikroba terjadi kontaminasi dari alat yang dipakai dan ada beberapa bagian yang sulit dibersihkan walaupun sudah disterilkan dengan alkohol.

Tabel 1 memperlihatkan bahwa penyimpanan 14 hari menyebabkan peningkatan jumlah pertumbuhan mikroba ikan pindang bumbu kuning. Perlakuan tanpa sterilisasi dan sterilisasi 5 menit menghasilkan jumlah total mikroba ikan pindang bumbu kuning sebesar $>1,0 \times 10^{5} \mathrm{CFU} / \mathrm{g}$, sehingga ikan pindang bumbu kuning dengan perlakuan tanpa sterilisasi cukup dianalisis sampai 
penyimpanan 14 hari karena jumlah mikroba yang mengkontaminasi ikan pindang bumbu kuning sudah melebihi standar SNI ikan pindang yang telah ditetapkan. Pada penyimpanan 28 hari, jumlah pertumbuhan mikroba ikan pindang bumbu kuning semakin banyak. Perlakuan sterilisasi 5 menit menghasilkan jumlah total mikroba ikan pindang bumbu kuning sebesar $>1,0 \times$ $10^{5} \mathrm{CFU} / \mathrm{g}$, sehingga ikan pindang bumbu kuning dengan perlakuan sterilisasi 5 menit cukup dianalisis sampai penyimpanan 28 hari karena jumlah mikroba yang mengkontaminasi ikan pindang bumbu kuning sudah melebihi standar SNI ikan pindang yang telah ditetapkan.

Tingginya total mikroba yang terdapat pada ikan pindang bumbu kuning meskipun sudah diberikan perlakuan sterilisasi disebabkan karena banyak faktor, diantaranya yaitu karakteristik dari ikan pindang bumbu kuning itu sendiri, ketahanan panas mikroba dan kelemahan dari botol kaca yang digunakan. Dilihat dari karakteristik bahan, ikan tergolong ke dalam bahan pangan yang memiliki kandungan gizi yang cukup tinggi seperti kandungan protein sekitar $262 \mathrm{mg} / 10 \mathrm{~g}$ bahan sehingga mudah terkontaminasi oleh mikroba perusak maupun pembusuk. Menurut Zakaria (1996) dalam Nur (2009), protein diuraikan oleh enzim-enzim proteolitik secara autolysis menjadi asam karboksilat, hydrogen disulfida $\left(\mathrm{H}_{2} \mathrm{~S}\right)$, ammonia dan asam lainnya. Lebih lanjut, proses kemunduran mutu oleh mikroorganisme yang menghasilkan sejumlah basa-basa yang mudah menguap seperti ammonia, histamine, indol, $\mathrm{H}_{2} \mathrm{~S}$, dan skatol yang berbau busuk. Ikan juga tergolong ke dalam bahan pangan yang memiliki kisaran $\mathrm{pH}$ yang netral yaitu sekitar $6,3-7,0$ sehingga tingkat kontaminasi oleh mikroorganisme menjadi tinggi. Nilai $\mathrm{pH}$ di atas 4,6 memungkinkan bakteri pembusuk anaerobik dan pembentuk spora yang patogen seperti Clostridium botulinum dapat tumbuh.

Ketahanan panas mikroba dipengaruhi oleh sejumlah faktor, antara lain umur dan keadaan organisme sebelum dipanaskan, komposisi medium pertumbuhan organisme, $\mathrm{pH}$ dan aw medium, waktu pemanasan, dan suhu pemanasan (Hariyadi, Kusnandar dan Wulandari, 2006). Bakteri pembusuk yang ada dalam makanan kaleng antara lain, bakteri yang banyak memproduksi gas hidrogen dan $\mathrm{CO}_{2}$ seperti Clostridium botulinum, Clostridium pasteurianum, C. thermosaccharolyticum, bakteri yang mempengaruhi $\mathrm{pH}$ makanan kaleng seperti Bacillus stearothermophillius, Bacillus coagulans, dan Byssochlamys fulva.

\section{Total Kapang}

Perlakuan pengaruh lama sterilisasi terhadap total kapang ikan pindang bumbu kuning selama penyimpanan 42 hari dapat dilihat pada Tabel 2.

Berdasarkan Tabel 2, total kapang pada semua perlakuan selama penyimpanan 0 hari, 14 hari, 28 hari dan 42 hari sangat rendah yaitu $<1,0 \times 10^{2} \mathrm{CFU} / \mathrm{g}$. Hal ini disebabkan karena ikan pindang bumbu kuning diberikan perlakuan sterilisasi sehingga tidak ada kapang yang dapat tumbuh. Makanan yang steril secara komersial berarti semua mikroorganisme penyebab penyakit dan pembentuk racun (toksik) dalam makanan tersebut telah dimatikan, demikian juga semua mikroorganisme pembusuk. Adapun untuk perlakuan tanpa sterilisasi (sterilisasi 0 menit), jumlah pertumbuhan kapang adalah $<1,0 \times 10^{2}$ $\mathrm{CFU} / \mathrm{g}$. Hal ini disebabkan karena ikan pindang bumbu kuning memiliki kandungan bumbu berupa kunyit $6 \%$ dan asam jawa $4 \%$. Menurut Handayani, dkk (2017), kombinasi bumbu kunyit $6 \%$ dan asam jawa $4 \%$ dalam proses pembuatan ikan pindang bumbu kuning mampu menekan pertumbuhan kapangkarena kunyit dan asam jawa mampu menekan pertumbuhan kapang, dimana kunyit dan asam jawa bertindak sebagai pengawet dan antimikroba alami.

Tabel 2. Purata Pengaruh Lama Sterilisasi terhadap Total Kapang Ikan Pindang Bumbu Kuning selama Penyimpanan 42 Hari

\begin{tabular}{ccccc}
\hline Lama & \multicolumn{4}{c}{ Total Kapang(CFU/g) } \\
\cline { 2 - 5 } Sterilisasi & \multicolumn{4}{c}{ Lama Penyimpanan (hari) } \\
\cline { 2 - 5 } (menit) & 0 & 14 & 28 & 42 \\
\hline 0 & $<1,0 \times 10^{2}$ & $<1,0 \times 10^{2}$ & TD & TD \\
5 & $<1,0 \times 10^{2}$ & $<1,0 \times 10^{2}$ & $<1,0 \times 10^{2}$ & TD \\
10 & $<1,0 \times 10^{2}$ & $<1,0 \times 10^{2}$ & $<1,0 \times 10^{2}$ & $<1,0 \times 10^{2}$ \\
15 & $<1,0 \times 10^{2}$ & $<1,0 \times 10^{2}$ & $<1,0 \times 10^{2}$ & $<1,0 \times 10^{2}$ \\
20 & $<1,0 \times 10^{2}$ & $<1,0 \times 10^{2}$ & $<1,0 \times 10^{2}$ & $<1,0 \times 10^{2}$ \\
25 & $<1,0 \times 10^{2}$ & $<1,0 \times 10^{2}$ & $<1,0 \times 10^{2}$ & $<1,0 \times 10^{2}$ \\
\hline Keterangan: TD $=$ Tidak Dilakukan
\end{tabular}

Secara umum pertumbuhan untuk kebanyakan kapang adalah sekitar $25-30{ }^{\circ} \mathrm{C}$. Beberapa jenis kapang bersifat psikrotrofik yakni dapat tumbuh baik pada suhu lemari es dan ada kapang yang masih bisa tumbuh secara lambat pada suhu dibawah suhu pembekuan, misalnya $-5^{\circ} \mathrm{C}$ sampai $-10^{\circ} \mathrm{C}$. Selain itu, ada kapang yang bersifat termofilik yang mampu tumbuh pada suhu di atas $50^{\circ} \mathrm{C}$ (Sanjaya, 2011 dalam Fernandez 2017). Sedangkan sterilisasi dilakukan pada suhu tinggi yaitu $121^{\circ} \mathrm{C}$ selama periode waktu tertentu sehingga dapat membunuh semua 
mikoba, termasuk kapang yang bersifat termofilik. Sifat kapang yang tidak tahan suhu tinggi ini yang menyebabkan tidak ada kapang yang tumbuh pada ikan pindang bumbu kuning sampai penyimpanan 42 hari.

\section{Daya Simpan}

Mutu daya simpan produk pangan merupakan mutu yang dapat diukur juga berdasarkan uji penerimaan secara visual (Tabel 3). Terdapat beberapa indikator yang menunjukkan produk pangan khusunya makanan kaleng mengalami kerusakan, seperti adanya perubahan warna, penggembungan kaleng dan bau (Arini, 2015). Menurut Kusumawardani (1994), kerusakan mutu ikan pindang ditandai dengan perubahan kenampakan menjadi tidak sesegar semula atau pudar, perubahan aroma dan rasa yang khas dari ikan pindang, kemudian sedikit demi sedikit timbul bau dan rasa yang tidak enak disertai dengan pertumbuhan kapang di permukaan kulit.

Tabel 3. Hasil Pengamatan Pengaruh Lama Sterilisasi terhadap Mutu Daya Simpan Ikan Pindang Bumbu Kuning selama Penyimpanan 42 Hari

\begin{tabular}{ccccc}
\hline Perlakua & \multicolumn{5}{c}{ Hari Terbentuk s.d Pengamatan 42 Hari } \\
\cline { 2 - 5 } (menit) & $\begin{array}{c}\text { Pertumbuha } \\
\text { n Kapang }\end{array}$ & $\begin{array}{c}\text { Penggembunga } \\
\text { n Tutup Botol }\end{array}$ & $\begin{array}{c}\text { Gelembun } \\
\text { g Gas }\end{array}$ & $\begin{array}{c}\text { Perubaha } \\
\text { n Warna }\end{array}$ \\
\hline 0 & - & 35 hari & 14 hari & 35 hari \\
5 & - & - & 25 hari & 42 hari \\
10 & - & - & 40 hari & - \\
15 & - & - & - & - \\
20 & - & - & - & - \\
25 & - & - & - & - \\
\hline
\end{tabular}

\section{Pertumbuhan Kapang secara Visual}

Berdasarkan Tabel 3, pengaruh lama sterilisasi yang berbeda terhadap mutu daya simpan ikan pindang bumbu kuning parameter pertumbuhan kapang secara visual tidak menunjukkan adanya pertumbuhan kapang selama penyimpanan. Hal ini disebabkan karena perlakuan panas yang diberikan saat mengalami proses sterilisasi akan mematikan semua jenis mikroorganisme seperti kapang. Sifat kapang yang tidak tahan suhu tinggi ini yang menyebabkan tidak ada kapang yang tumbuh pada ikan pindang bumbu kuning selama penyimpanan 42 hari. Selain itu, proses pengalengan juga menggunakan kemasan yang hermetis sehingga kebutuhan oksigen untuk pertumbuhan kapang menjadi tidak tersedia karena kapang membutuhkan kondisi yang aerob untuk pertumbuhannya. Handayani, dkk (2017) menyatakan bahwa kombinasi bumbu kunyit $6 \%$ dan asam jawa $4 \%$ dalam proses pembuatan ikan pindang bumbu kuning mampu menekan pertumbuhan kapangkarena kunyit dan asam jawa mampu menekan pertumbuhan kapang, dimana kunyit dan asam jawa bertindak sebagai pengawet dan antimikroba alami. Menurut penelitian Fernandez (2017) tentang pengaruh lama sterilisasi terhadap gulai remis dalam kemasan botol mampu menekan pertumbuhan kapang. Sedangkan menurut penelitian Wahyuni (2017), sterilisasi yang dilakukan pada suhu tinggi yaitu $121^{\circ} \mathrm{C}$ selama periode waktu tertentu mampu membunuh semua mikoba, termasuk kapang yang bersifat termofilik. Oleh karena itu, pengaruh lama sterilisasi terhadap ikan pindang bumbu kuning kaleng ini tidak menunjukkan adanya pertumbuhan kapang secara visual selama penyimpanan.

\section{Penggembungan Tutup Botol}

Berdasarkan hasil pengamatan, perlakuan lama sterilisasi yang berbeda berpengaruh terhadap mutu daya simpan ikan pindang bumbu kuning selama penyimpanan 42 hari pada parameter penggembungan tutup botol. Pada Tabel 3, perlakuan tanpa sterilisasi menghasilkan penggembungan tutup botol ikan pindang bumbu kuning pada penyimpanan ke35 hari. Sedangkan perlakuan dengan sterilisasi 5 menit, 10 menit, 15 menit, 20 menit dan 25 menit tidak menunjukkan adanya penggembungan tutup botol. Adanya penggembungan tutup botol ini dapat dilihat secara visual serta ditandai dengan adanya perbedaan bunyi yang dihasilkan apabila tutup botol diketuk. Menurut teori Resonansi Bunyi, semakin luas kolom udara maka suara yang dihasilkan akan semakin nyaring (Tipler, 1991). Hal ini terlihat pada perlakuan sterilisasi 0 menit menunjukkan adanya penggembungan tutup botol menghasilkan suara tidak nyaring apabila diketuk karena terdapatnya udara berupa $\mathrm{CO}_{2}$ pada sampel sedangkan perlakuan dengan sterilisasi mengeluarkan suara nyaring apabila tutup botol diketuk. Penggembungan tutup botol ikan pindang bumbu kuning ini disebabkan karena pertumbuhan mikroorganisme yang tinggi akan menghasilkan asam dan $\mathrm{CO}_{2}$ sehingga menyebabkan tutup botol menjadi menggembung. Menurut Slamethandono (2011), kerusakan makanan kaleng disebabkan karena adanya pertumbuhan bakteri termofilik dan mesofilik. Jenis bakteri termofilik yang tumbuh pada makanan kaleng adalah Bacillus stearothermophilus menyebabkan busuk asam pada makanan kaleng berasam rendah. Bakteri termofil lainnya yang bersifat anerob yaitu Clostridium thermosaccharolyticum menyebabkan penggembungan kaleng karena 
memproduksi $\mathrm{CO}_{2}$ dan $\mathrm{H}_{2}$. Sedangkan jenis bakteri mesofilik pembentuk spora yang tumbuh adalah Clostridium pasteurianum dan Clostridium butyricum. Kerusakan ini terjadi karena, perlakuan tanpa sterilisasi (sterilisasi 0 menit) tidak menggunakan suhu tinggi sehingga pertumbuhan mikroba mesofilik maupun termofilik menjadi tinggi sehingga dapat memproduksi asam butirat, $\mathrm{CO}_{2}$ dan $\mathrm{H}_{2}$ dan menyebabkan penggembungan kaleng.

\section{Adanya Gelembung Gas}

Pembentukan gelembung gas ikan pindang bumbu kuning selama penyimpanan 42 hari dapat dilihat pada Gambar 2.

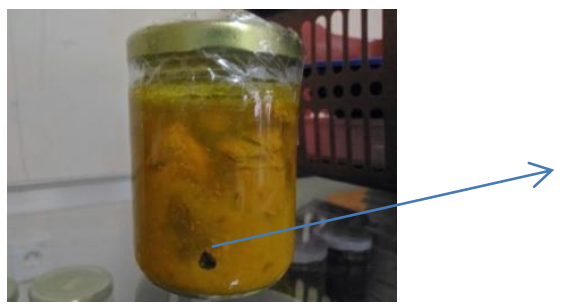

Gelembung gas

Gambar 2. Pembentukan Gelembung Gas Ikan Pindang Bumbu Kuning selama Penyimpanan 42 Hari

Berdasarkan Tabel 3, perlakuan sterilisasi 0 menit menunjukkan adanya pembentukan gelembung gas pada sampel ikan pindang bumbu kuning pada penyimpanan ke14 hari. Menurut Slamethandono (2011), indikator kerusakan makanan kaleng ditandai dengan adanya pembentukan gelembung gas pada bahan. Pembentukan gas ini ini disebabkan karena pertumbuhan mikroorganisme yang tinggi akan menghasilkan $\mathrm{H}_{2}$ dan $\mathrm{CO}_{2}$. Jumlah $\mathrm{CO}_{2}$ yang dihasilkan akan menyebabkan terdapatnya gas pada botol. Jenis mikroba penghasil gas dan asam adalah Bacillus stearothermophilus, B.thermoacidurans, dan Clostridium thermosaccarolyticum merupakan anggota kelompok bakteri termofilik $\left(50-55^{\circ} \mathrm{C}\right)$ serta Clostridium botulinum. Perlakuan sterilisasi 5 menit menunjukkan adanya pembentukan gelembung gas pada sampel ikan pindang bumbu kuning pada penyimpanan ke-25 hari. Sedangkan perlakuan sterilisasi 10 menit menunjukkan terjadinya pembentukan gas pada penyimpanan ke-40 hari. Adanya pembentukan gas pada perlakuan sterilisasi 5 menit dan 10 menit disebabkan karena kurangnya waktu yang dibutuhkan untuk melakukan proses sterilisasi sehingga terjadi under proces (kurangnya proses pemanasan). Under proces ini akan menyebabkan mikroba penyebab kebusukan ataupun patogen terutama mikroba mesofilik tidak mati sehingga jumlah pertumbuhan mikroba menjadi banyak dan menyebabkan kebusukan pada makanan kaleng dan memproduksi $\mathrm{H}_{2}, \mathrm{CO}_{2}$ dan asam.

\section{Perubahan Warna}

Warna merupakan salah satu aspek yang penting dalam bahan pangan baik untuk menentukan tingkat acceptability maupun kualitas bahan pangan itu sendiri. Contoh perubahan warna ikan pindang bumbu kuning selama penyimpanan 42 hari dapat dilihat pada Gambar 3.

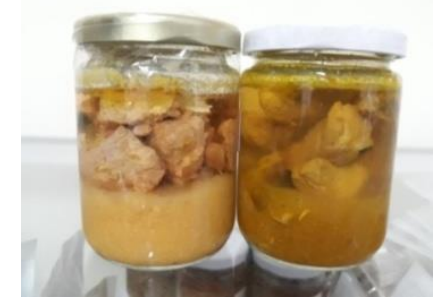

Gambar 3. Perubahan Warna Ikan Pindang Bumbu Kuning selama Penyimpanan 42 Hari (kanan = sebelum penyimpanan, kiri = setelah penyimpanan)

Berdasarkan Tabel 3, perubahan daya simpan dengan parameter perubahan warna ikan pindang bumbu kuning untuk perlakuan sterilisasi 0 menit terbentuk pada hari ke-35. Perlakuan sterilisasi 5 menit perubahan wana ikan pindang bumbu kuning mulai terbentuk pada penyimpanan ke-42 hari. Sedangkan untuk perlakuan sterilisasi 10 menit, 25 menit, 20 menit dan 25 menit tidak terbentuk perubahan warna sampai penyimpanan 42 hari. Hal ini disebabkan karena kandungan mikroba yang tinggi akan mempengaruhi perubahan warna pada bahan menjadi kusam dan pucat. Semakin tinggi jumlah mikroba dalam bahan pangan dan semakin cepat proses oksidasi bahan pangan, maka semakin kecil nilai kecerahan. Hal ini diakibatkan oleh penguraian senyawa-senyawa tertentu pada bahan pangan tersebut (terutama pigmen), selain itu terjadi reaksi perubahan warna secara enzimatis yang menyebabkan penurunan tingkat kecerahan bahan pangan, bahkan dapat membuat bahan pangan menjadi berwarna kusam atau pucat. Dengan adanya pertumbuhan mikroba, maka akan menyebabkan menurunnya tingkat kecerahan pada bahan sehingga menjadi lebih kusam dan tidak cemerlang. Hal yang sama juga diungkapkan menurut Rachmat, Edison 
dan Sumarto (2015) bahwa penurunan pH akan menyebabkan warna daging menjadi semakin pucat. Warna pucat ini disebabkan karena semakin banyaknya air bebas yang berada diluar daging ikan. Kandungan air ekstraseluler yang tinggi akan menyebabkan kemampuannya untuk memantulkan cahaya akan meningkat dan penyerapan cahaya menurun sehingga intensitas warna menurun (kurang cemerlang).

\section{Mutu Organoleptik Aroma}

Perlakuan pengaruh lama sterilisasi terhadap aroma ikan pindang bumbu kuning selama penyimpanan 42 hari dapat dilihat pada Gambar 4.

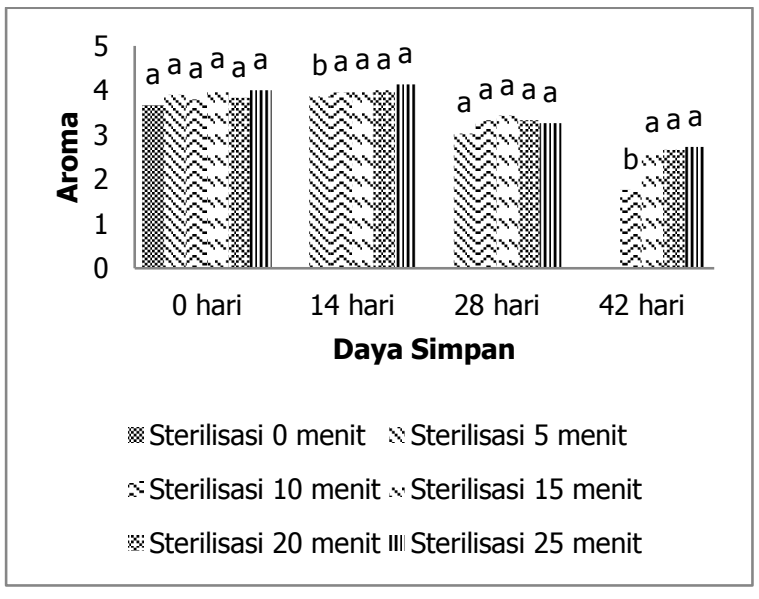

Keterangan: TD = Tidak Dilakukan

Gambar 4. Grafik Pengaruh Lama Sterilisasi terhadap Organoleptik Aroma (Hedonik) Ikan Pindang Bumbu Kuning

Berdasarkan Gambar 4, perlakuan lama sterilisasi memberikan pengaruh yang berbeda nyata terhadap nilai kesukaan aroma ikan pindang kuning pada penyimpanan hari ke-14 dan hari ke-42, namun memberikan pengaruh yang tidak berbeda nyata terhadap nilai kesukaan aroma ikan pindang kuning pada penyimpanan hari ke-0 dan hari ke-28. Pada penyimpanan 0 hari memberikan pengaruh yang tidak berbeda nyata dan panelis cendrung memilih kriteria suka karena menghasilkan aroma khas ikan pindang kaleng, hal ini karena ikan pindang bumbu kuning belum ada pengaruh dari faktor luar. Kemudian pada penyimpanan hari ke-14, perlakuan lama sterilisasi menghasilkan perbedaan yang nyata terhadap mutu hedonik aroma ikan pindang bumbu kuning namun masih dalam kriteria suka. Pada penyimpanan hari ke-28, perlakuan lama sterilisasi tidak memberikan pengaruh yang berbeda nyata terhadap tingkat kesukaan panelis aroma ikan pindang bumbu kuning karena ikan pindang bumbu kuning belum mengalami kerusakan sehingga panelis memilih kriteria agak suka. Hal ini juga berkaitan dengan nilai $\mathrm{pH}$ yang dihasilkan pada penyimpanan hari ke-28 tidak memiliki perbedaan yang nyata sehingga tingkat kesukaan aroma ikan pindang bumbu kuning memiliki aroma yang hampir sama. Pada penyimpanan hari ke-42, perlakuan lama sterilisasi 10 menit menurunkan tingkat kesukaan panelis menjadi kriteria tidak suka. Sedangkan perlakuan sterilisasi 15 menit, 20 menit dan 25 menit masih dengan kriteria agak suka. Hal ini disebabkan karena mikroba dapat mengurai protein yang terdapat pada bahan sehingga menghasilkan asam karboksilat, amoniak, hidrogen disulfida, indol dan skatol yang menimbulkan aroma asam dan berbau busuk (Kaparang, 2013). Menurut penelitian Rachmat, Edison dan Sumarto (2015) tentang perubahan bau ikan pindang presto jelawat dengan pengemasan vakum selama penyimpanan menunjukkan semakin lamanya masa simpan, maka menurunkan tingkat penerimaan panelis terhadap bau pindang yang dihasilkan. Hal ini disebabkan karena penguraian komponen komponen kimia pindang presto sehingga menyebabkan bau busuk dan tengik. Penyimpangan bau dan aroma yang terjadi pada produk perikanan disebabkan oleh adanya enzim dan mikroorganisme. Hal ini sesuai dengan Frazier dan Dennis (1988) dalam Rachmat, Edison dan Sumarto (2015) yang menyatakan penyimpangan aroma disebabkan dekomposisi protein, peptida, asam amino yang menyebabkan bau busuk dan disebut putrefaksi. Reaksi tersebut menghasilkan senyawa yang mengandung sulfur (hidrogen sulfida, metilsulfida, merkaptan) ammonia, amina (histamin, tiramin, piperdin, putresin, dan kadaverin) indol, skatol, dan asam lemak tak jenuh.

\section{Kenampakan}

Perlakuan pengaruh lama sterilisasi terhadap kenampakan ikan pindang bumbu kuning selama penyimpanan 42 hari dapat dilihat pada Gambar 5.

Perlakuan lama sterilisasi (Gambar 5) memberikan pengaruh yang berbeda nyata terhadap nilai kesukaan kenampakan ikan pindang kuning pada penyimpanan hari ke-0, hari ke-28 dan hari ke-42, namun memberikan pengaruh yang tidak berbeda nyata terhadap 
nilai kesukaan kenampakan ikan pindang kuning pada penyimpanan hari ke-14. Perbedaan yang nyata pada penyimpanan hari ke-0 ini disebabkan karena waktu sterilisasi yang tepat akan menyebabkan kenampakan ikan pindang yang dikalengkan akan menjadi semakin bagus sehingga berpengaruh terhadap tingkat kesukaan panelis. Perlakuan sterilisasi 5 menit, 10 menit, 15 menit, 20 menit dan 25 menit menunjukkan kriteria suka terhadap kenampakan ikan pindang kuning karena menghasilkan kenampakan ikan pindang seperti utuh, ada sedikit serpihan, bersih terdiri dari daging putih kekuningan serta cemerlang. Sedangkan perlakuan sterilisasi 0 menit menghasilkan kriteria agak suka karena menghasilkan kenampakan yang cenderung banyak serpihan, bersih dan sedikit kurang cemerlang.

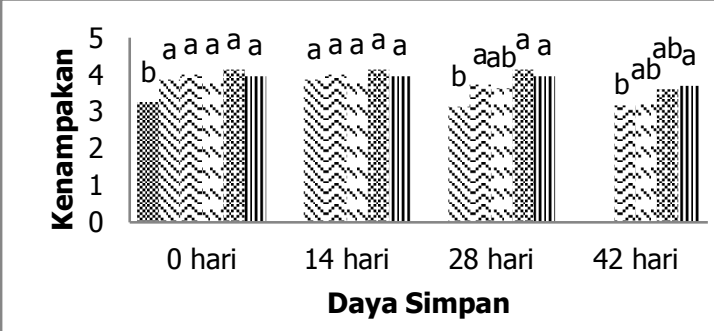

Sterilisasi 0 menit Sterilisasi 5 menit

$\therefore$ Sterilisasi 10 menit $\times$ Sterilisasi 15 menit

x Sterilisasi 20 menit III Sterilisasi 25 menit

Keterangan: TD = Tidak Dilakukan

Gambar 5. Grafik Pengaruh Lama Sterilisasi terhadap Organoleptik Kenampakan (Hedonik) Ikan Pindang Bumbu Kuning

Pada penyimpanan hari ke-14, perlakuan lama sterilisasi tidak memberikan pengaruh yang berbeda nyata terhadap tingkat kesukaan panelis parameter kenampakan ikan pindang bumbu kuning karena ikan pindang bumbu kuning belum mengalami kerusakan sehingga panelis memilih kriteria suka. Kriteria suka ini dipilih berdasarkan tingkat peniliaian panelis terhadap kenampakan ikan pindang bumbu kuning yang dikemas dengan kemasan botol menghasilkan kenampakan seperti banyak serpihan, kurang bersih, terdiri dari daging putih dan merah, serta kurang cemerlang. Kemudian pada penyimpanan hari ke-28, perlakuan sterilisasi 5 menit menurunkan tingkat kesukaan panelis terhadap kenampakan ikan pindang kuning menjadi kriteria agak suka karena menghasilkan ikan pindang kuning seperti banyak serpihan dan kurang cemerlang. Pada penyimpnan hari ke42, tingkat kesukaan panelis terhadap kenampakan ikan pindang kuning kaleng menurun menjadi kriteria agak suka pada semua perlakuan. Perubahan kenampakan ikan pindang kuning ini dipengaruhi oleh terjadinya perubahan warna semakin dengan lamanya penyimpanan. Dengan adanya pertumbuhan mikroba, maka akan menyebabkan menurunnya tingkat kecerahan pada bahan sehingga menjadi lebih kusam dan tidak cemerlang. Hal yang sama juga diungkapkan menurut Rachmat, Edison dan Sumarto (2015) bahwa penurunan $\mathrm{pH}$ akan menyebabkan warna daging menjadi semakin pucat. Warna pucat ini disebabkan karena semakin banyaknya air bebas yang berada diluar daging ikan. Kandungan air ekstraseluler yang tinggi akan menyebabkan kemampuannya untuk memantulkan cahaya akan meningkat dan penyerapan cahaya menurun sehingga intensitas warna menurun (kurang cemerlang). Menurut Buckle et al., dalam Rachmat, Edison dan Sumarto (2015) Semakin lama masa simpan ikan, maka nilai rupa ikan terus menurun, hal tersebut disebabkan oleh perubahan-perubahan secara fisik maupun kimiawi. Perlakuan fisik dan kimiawi dari suatu bahan pangan dapat disebabkan pertumbuhan organisme yang mengakibatkan rusaknya struktur bahan pangan menjadi lunak dan berair sehingga penampakan tidak cemerlang.

\section{Rasa}

Perlakuan pengaruh lama sterilisasi terhadap rasa ikan pindang bumbu kuning selama penyimpanan 42 hari dapat dilihat pada Gambar 6.

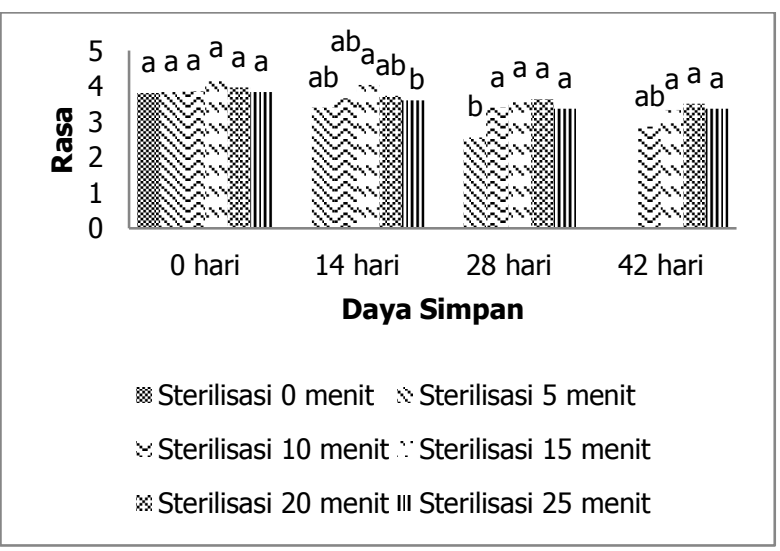

Keterangan: TD = Tidak Dilakukan

Gambar 6. Grafik Pengaruh Lama Sterilisasi terhadap Organoleptik Rasa (Hedonik) Ikan Pindang Bumbu Kuning 
Berdasarkan Gambar 6, perlakuan lama sterilisasi memberikan pengaruh yang tidak berbeda nyata terhadap nilai kesukaan rasa ikan pindang kuning pada penyimpanan hari ke-0 dan hari ke-42, namun berbeda nyata pada hari ke-14 dan hari ke-28.

Pada penyimpanan 0 hari memberikan pengaruh yang tidak berbeda nyata terhadap tingkat kesukaan rasa ikan pindang dan panelis cendrung memilih kriteria suka, hal ini disebabkan karena ikan pindang bumbu kuning belum ada pengaruh dari faktor luar. Sedangkan penyimpanan 14 hari menunjukkan hasil yang berbeda nyata. Perlakuan sterilisasi 5 menit menghasilkan kriteria agak suka terhadap rasa ikan pindang kuning karena menghasilkan rasa yang tidak enak atau hambar. Hal ini disebabkan karena pH ikan pindang bumbu kuning yang berbeda dapat mempengaruhi rasa. Sedangkan pada penyimpanan 28 hari, perlakuan lama sterilisasi $10,15,20$ dan 25 menit menghasilkan hasil yang tidak berbeda nyata dan menghasilkan kriteria suka sampai agak suka dan pada penyimpanan 42 hari menunjukkan hasil yang tidak berbeda nyata dan menurunkan tingkat kesukaan panelis menjadi agak suka. Nilai rerata terendah terdapat pada perlakuan sterilisasi 10 menit karena menghasilkan ikan pindang yang kurang enak, hambar dan agak basi. Menurut penelitian Rachmat, Edison dan Sumarto (2015) tentang perubahan rasa ikan pindang jelawat dengan pengemasan vakum selama penyimpanan menunjukkan semakin lamanya masa simpan, maka nilai rasa ikan tersebut akan semakin menurun. Hal ini disebabkan perubahan kadar air dan oksigen yang terdapat didalam kemasan pindang presto vakum dan kemasan pindang presto non vakum. Perubahan ini secara tidak langsung akan mempengaruhi perubahan nilai protein (sebagai akibat hidrolisis dan oksidasi), kinerja enzimatis dan mikrobiologi. Hal ini juga disampaikan (Hadiwiyoto, 1993) yang mengakatakan penurunan cita rasa bahan pangan disebabkan oleh penguraian protein, lemak, karbohidrat melalui proses kimiawi yang terjadi akibat reaksi enzimatis.

\section{Tekstur}

Perlakuan pengaruh lama sterilisasi terhadap rasaikan pindang bumbu kuning selama penyimpanan 42 hari dapat dilihat pada Gambar 7.

Gambar 7 memperlihatkan bahwa perlakuan lama sterilisasi memberikan pengaruh yang tidak berbeda nyata terhadap nilai kesukaan tekstur ikan pindang kuning pada penyimpanan hari ke-0 namun berbeda nyata pada hari ke-14 hari, ke-28 dan hari ke42. Pada penyimpanan 0 hari memberikan pengaruh yang tidak berbeda nyata, hal ini disebabkan karena ikan pindang bumbu kuning belum ada pengaruh dari faktor luar. Sedangkan pada penyimpanan 14 hari menunjukkan hasil yang berbeda nyata terhadap tekstur (Hedonik) ikan pindang bumbu kuning, dimana perlakuan sterilisasi 5 menit berbeda nyata dengan perlakuan sterilisasi 10 menit, 15 menit, 20 menit dan 25 menit, sedangkan perlakuan yang lainnya memberikan hasil yang tidak berbeda nyata. Hal ini disebabkan karena ikan pindang bumbu kuning yang diberikan perlakuan sterilisasi 5 menit sudah mulai rusak dan menurunkan tingkat kekompakan dan kepadatan ikan pindang selama penyimpanan sehingga panelis memilih kriteria agak suka. Sedangkan untuk sampel yang diberi perlakuan sterilisasi 10 menit, 15 menit, 20 menit dan 25 menit masih normal sehingga panelis memilih kriteria suka.

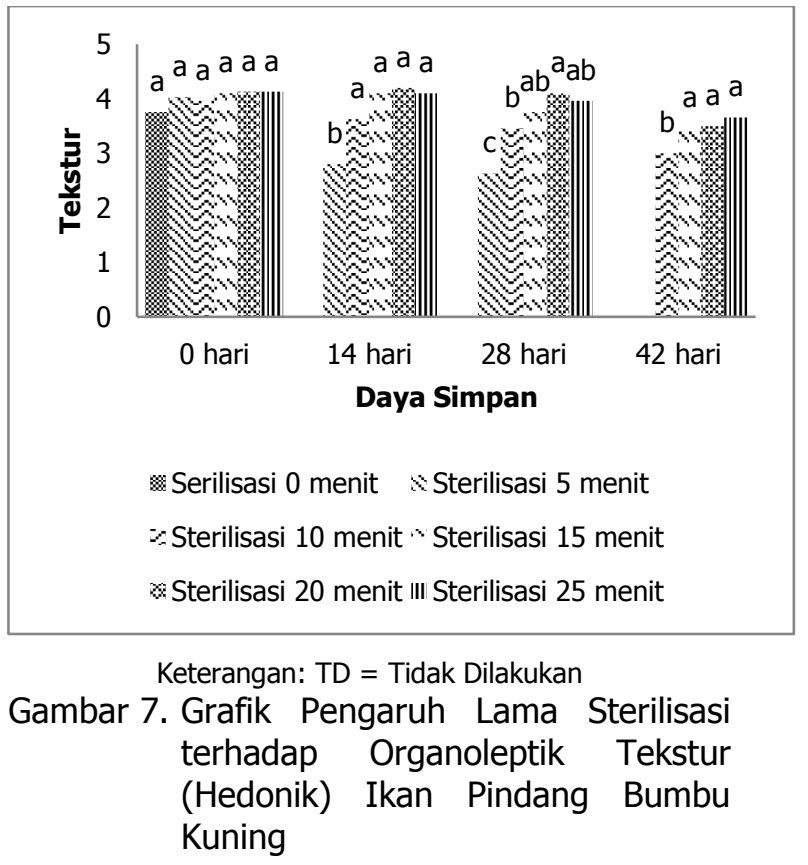

Sedangkan penyimpanan 28 hari menunjukkan hasil yang berbeda nyata terhadap tekstur ikan pindang. Perlakuan dengan sterilisasi 20 menit menghasilkan rerata tertinggi dengan kriteria suka dan terendah terdapat pada perlakuan sterilisasi 5 menit dengan kriteria agak suka. Hal ini disebabkan karena pada perlakuan sterilisasi 5 menit terdapat pertumbuhan mikroba yang tinggi sehingga kemampuan dalam mengurai bahan menjadi senyawa-senyawa sederhana menjadi 
semakin tinggi dan menurunkan tingkat kepadatan pada sampel ikan pindang. Pada penyimpanan 42 hari, perlakuan sterilisasi 15 menit, 20 menit dan 25 menit menghasilkan hasil yang tidak berbeda nyata dan menghasilkan kriteria agak suka sampai suka sedangkan sampel dengan perlakuan sterilisasi 10 menit menunjukkan kriteria agak suka. Hal ini menunjukkan bahwa perlakuan sterilisasi 15 menit, 20 menit dan 25 menit mampu mempertahankan tekstur ikan pindang bumbu kuning sampai penyimpanan 42 hari. Menurut penelitian Rachmat, Edison dan Sumarto (2015) tentang perubahan tekstur ikan pindang jelawat dengan pengemasan vakum selama penyimpanan menunjukkan semakin lamanya masa simpan, maka nilai tekstur ikan tersebut akan semakin menurun. Hal ini disebabkan oleh aktifitas air bahan pangan dan perbedaan kelembaban antara bahan pangan dengan lingkungan penyimpanan akan mengakibatkan perubahan aktifitas air.

\section{KESIMPULAN}

Lama sterilisasi memberikan pengaruh yang berbeda nyata terhadap nilai $\mathrm{pH}$ ikan pindang bumbu kuning selama penyimpanan 0 , 14 dan 42 hari, namun tidak berpengaruh pada penyimpanan 28 hari. Perlakuan sterilisasi 15 sampai dengan 25 menit dapat menghasilkan total mikroba dan total kapang yang sesuai dengan standar SNI 2717.1:2009, mampu mempertahankan mutu organoleptik dari parameter kenampakan, aroma, rasa dan tekstur selama penyimpanan 42 hari pada suhu ruang dan mempertahankan mutu daya simpan ikan pindang bumbu kuning dari pertumbuhan kapang secara visual, mencegah penggembungan tutup botol, pembentukan gelembung gas dan perubahan warna ikan pindang bumbu kuning. Lama sterilisasi 15 menit direkomendasikan sebagai lama sterilisasi minimal yang digunakan untuk meningkatkan mutu ikan pindang bumbu kuning dilihat dari nilai $\mathrm{pH}$, jumlah total mikroba, jumlah total kapang, mutu daya simpan serta mutu organoleptik produk.

\section{UCAPAN TERIMA KASIH}

Ucapan terima kasih disampaikan kepada Kemenristekdikti yang ikut mendanai penelitian ini melalui skim Penelitian Strategis Nasional 2018.

\section{DAFTAR PUSTAKA}

Adawyah R. 2007. Pengolahan dan Pengawetan Ikan. PT. Bumi Aksara, Jakarta.

Arini LDD. 2015. Faktor-faktor Penyebab dan Karakteristik Makanan Kadaluarsa yang Berdampak Buruk pada Kesehatan Masyarakat. APIKES Citra Medika Surakarta, Surakarta.

Badan Standardisasi Nasional (BSN). 2004. Penentuan Kadar pH. SNI 06-6989.112004. Badan Standarisasi Nasional, Jakarta

Badan Standardisasi Nasional (BSN). 2006. Petunjuk Pengujian Angka Lempeng Total (ALT) Produk Perikanan. SNI 012332.3-2006. Badan Standardisasi Nasional, Jakarta.

Badan Standarisasi Nasional (BSN). 2009. Tentang Ikan Pindang-Bagian 1: Spesifikasi. SNI 2717.1:2009. Badan Standarisasi Nasional, Jakarta.

Badan Standardisasi Nasional (BSN). 2011. Petunjuk Pengujian Organoleptik dan atau Sensori pada Produk Perikanan. SNI 2346-2011. Badan Standardisasi Nasional, Jakarta.

Badan Pusat Statistik, 2013. Perikanan. https://www.bps.go.id. [6 6 Oktober 2017].

Dahuri, R., 2012. Potensi Perikanan Indonesia. www.antaranews.com/berita/34966/p otensi-perikanan-indonesia-barutergarap-20-persen.html. [6 Oktober 2017].

Ekawati, Y., 2014. Perubahan Komposisi Asam Amino dan Mineral Ikan Cakalang (Katsuwonus pelamis) akibat Proses Penggorengan. [Skripsi]. Bogor: Fakultas Perikanan dan Ilmu Kelautan, Institut Pertanian Bogor.

Fernandez CDW. 2017. Pengaruh Lama Sterilisasi dalam Botol Gelas terhadap Mutu Gulai Remis (Corbicula javanica). [Skripsi]. Mataram: Fakultas Teknologi Pangan dan Agroindustri. Universitas Mataram.

Hadiwiyoto S. 1993. Teknologi Pengolahan Hasil Perikanan Jilid I. Liberty, Jakarta.

Handayani BR, Kusumo BD, Werdiningsih W, Rahayu TI, dan Sugita DL. 2017. Microbial quality of yellow seasoned 
"pindang' fish treated with turmeric and tamarind. International Symposium on Food and Agro-biodiversity (ISFA) 2017. IOP Conference Series: Earth and Environmental Science 102 (2018) 012019: 1-9.doi : 10.1088/17551315/102/1/012019.

Hariyadi P, Kusnandar, dan Wulandari N. 2006. Prinsip dan Pengertian Proses Termal. Pusat Studi Pangan dan Gizi. Institut Pertanian Bogor, Bogor.

Hawora D. 2013. Strategi pengembangan pengolahan hasil perikanan di kabupaten donggala. J Agroland, 20 (1): 75-81.

Kaparang R, Harikedua SD dan Suwetja IK. 2013. Penentuan mutu ikan tandipang (Dussumieria acuta C.V) asap kering selama penyimpanan suhu kamar. Jurnal Media Teknologi Hasil Perikanan, 1(1): 1-6.

Kusumawardani H. 1994. Pengawetan dan Perbaikan Mutu Ikan Pindang. Teknologi dan Kejuruan, FpTK IKIP Malang, 1: 121-128.

Nur M. 2009. Pengaruh cara pengemasan, jenis bahan pengemas, dan lama penyimpanan terhadap sifat kimia, mikrobiologi, dan organoleptik sate bandeng (Chanos chanos). Jurnal Teknologi dan Industri Hasil Pertanian, 14(1): 1-11.

Nurhikmat A, Suratmo B, Bintoro $\mathrm{N}$ dan Suharwadji. 2016. Pengaruh suhu dan waktu sterilisasi terhadap nilai $\mathrm{F}$ dan fisik kaleng kemasan pada pengalengan gudeg. Agritech, 36(1): 71-78.

Nuridha A, dan Basirun. 2013. Pengolahan rendang patin dalam kaleng. The processing technique of canned catfish "Rendang". Jurnal Pasca Panen Perikanan. Cipayung. Jakarta Timur.

Rachmat D, Edison dan Sumarto, 2015. Kajian Komperatif Mutu Pindang Presto Ikan Jelawat (Leptobarbus heoveni) dengan Pengemasan Metode Vakum dan Non Vakum selama Penyimpanan. [Skripsi]. Riau: Fakultas Perikanan dan Ilmu Kelautan, Universitas Riau.
Saputra S. 2006. Mempelajari Pengaruh Blansir, Sterilisasi Komersial dan Pengemasan terhadap Umur Simpan Tempe. [Skripsi]. Bogor: Fakultas Teknologi Pertanian, Institut Petanian Bogor.

Sholihah A. 2011. Proses Pengalengan Kalio Daging Sapi dan Kajian Pengaruh Sterilitas (Fo) Pemanasan pada Berbagai Suhu terhadap Perubahan Sifat Fisiknya. [Skripsi]. Bogor: Faculty of Agricultural Technology, Bogor Agricultural University.

Slamethandono. 2011. Kerusakan Bahan Pangan.

http://skp.unair.ac.id/repository/GuruIndonesia/kerusakanbahanpang_slame thandono_11964.pdf [2 Mei 2018].

Sugita DL. 2017. Pengaruh Penambahan Konsentrasi Kunyit dan Asam Jawa terhadap Beberapa Komponen Mutu Ikan Pindang Bumbu Kuning. [Skripsi]. Mataram: Fakultas Teknologi Pangan dan Agroindustri, Universitas Mataram.

Suryaningrum DT, Syamdidi dan Rizki EM. 2013. Penggunaan berbagai garam dan bumbu pada pengolahan pindang ikan lele dumbo (Clarias gariepinus). JPB Kelautan dan Perikanan, 8(1): 23-34.

Tipler PA. 1991. Fisika untuk Sains dan Teknik, Edisi Ketiga, Jilid I. Erlangga, Jakarta.

Utami R. 2012. Karakteristik Pemanasan pada Proses Pengalengan Gel Cincau Hitam (Mesona palustris). [Skripsi]. Bogor: Fakultas Teknologi Pertanian. Institut Pertanian Bogor.

Wally E, Mentang F dan Montolalu RI. 2015. Kajian mutu kimiawi ikan cakalang (Katsuwonus pelamis L.) asap (Fufu) selama penyimpanan suhu ruang dan suhu dingin. Jurnal Media Teknologi Hasil Perikanan, 3(1): 8-12.

Wahyuni ZA. 2017. Pengaruh Lama Sterilisasi pada Proses Pengalengan terhadap Mutu dan Masa Simpan Ares. [Skripsi]. Mataram: Fakultas Teknologi Pangan dan Agroindustri, Universitas Mataram.

Yuswita E. 2014. Optimasi proses termal untuk membunuh Clostridium botulinum. Jurnal Aplikasi Teknologi Pangan, 3(3): 5-6. 